\title{
ПІДПРИЕМНИЦТВО
}

KHARSUN Liudmyla,

$\mathrm{PhD}$ (Economics), Associate Professor of the Department

of Trade Entrepreneurship and Logistics

of Kyiv National University of Trade and Economics

19, Kyoto str., 19, Kyiv, 02156, Ukraine

E-mail:l.kharsun@knute.edu.ua

ORCID: http://orcid.org/0000-0002-7569-934\%20X
PATKOVSKYI Serhii, Route development manager, business practitioner Kuehne+Nagel Inc., Chicago, IL USA

E-mail:sergey.patkovskiy@gmail.com

\section{THE COLD SUPPLY CHAINS OF FOOD: DETERMINANTS OF MANAGEMENT AND DEVELOPMENT}

This paper deals with cold chains essences. It identifies main preconceptions of the cold chain market development in Ukraine and worldwide. The main characteristics of the cold supply chains are determined. The current state and development perspectives of the cold chain logistics on the food market in Ukraine have been analyzed.

Keywords: cold logistics, cold supply chain, perishable goods, temperature control mode, logistic services.

Харсун Л., Патковский С. Холодовые цепи поставки продовольствия: детерминанты управления и развития. Рассмотрена сущность холодовых цепей поставки. Установлены основные предпосылки развития рынка холодовой логистики в Украине и в мире. Выявлены основные характерные черты холодовых иеепей поставок. Проанализировано современное состояние и перспективы развития системы логистического обеспечения холодовых иеепей поставок продовольственных товаров в Украине.

Ключевые слова: холодовая логистика, холодовая цепь поставки, скоропортящиеся товары, температурный режим, логистическое обеспечение.

Background. Merchandise markets globalization strives to overcome production and consumption location of wide range of goods, eliminate transaction barriers, equalize product's quality and operational standards requirements. All this creates new challenges for cold chain logistics covering wide-spread variety of merchandise flows.

At the same time high pace of technical and technological resources development creates vast capabilities for trade and social necessities solving, providing those consumption locations goods availability that were hardly accessible due to strict delivery time requirements. First of all considering

(C) Kharsun L., Patkovskyi S., 2020 
perishable goods with limited lifetime end highly sensitive to the temperature mode deviations during their storage and transportation. Thereby research of scientific and practical grounds of economic, technical and technological aspects of cold chains practices is becoming of main significance.

Analysis of recent researches and publications. Cold chains matter is covered by a number of national and foreign experts publications, in particular Y. Krykavskyy, T. Nakonechna [1], M. Saiensus, O. Goryayinov, K. Zamaryonova, Dr. J.-P. Rodrigue, Dr. T. Notteboom [2; 3], E. Vather [4], P. Burnson and others.

The essence of the cold supply chains, the features of the interaction between their participants and of their functioning technical support are disclosed in the articles of Y. Krykavskyy, T. Nakonechna [1]. Dr. J.-P. Rodrigue [2; 3] in his publications focuses on the specifics of food cold supply chains managing, identifying their elements, risks and operations. Analysis of the global cold logistics market, its capacity and development trends are the subject of research E. Vather [4] as well as a number of analytical materials [5-7]. Factual data on the potential of cold supply chains of food, their infrastructure support, problems and prospects of their development are presented in a number of statistical reviews and analytical materials [8-13].

A considerable number of publications on the topic of cold logistics are focused on the study of the supply chains of certain foodstuffs or pharmaceutical products. Among the authors of such investigations are V. Vostryakova, O. Posilkina, A. Khromikh, R. Sahaidak-Nikityuk in particular.

However there is a lack of research of integrated methods of cold chains management and their logistics organization which would be based on their specific features.

The aim of this study is to analyze, determine and systemize key logistics characteristics of cold chains; assess present state of cold food chains logistics services in Ukraine and its development perspectives.

Materials and methods. During this research we used studies and papers of national and international experts, analytical reviews and comments provided by cold chains market players, data reports provided by the State statistics service of Ukraine. In order to achieve the goal of the study we have used comparison, synthesis, systemization and generalization methods.

Results. Cold chain logistics is not a new issue, since perishable goods transportation has been existing for a long time. However, considering cold chain from the integrated perspective the history of its development started in 1797 when British fishermen had been moving caught fish covered by a layer of ice. But as a separate professional logistics segment cold chain logistics has been functioning since 1950s when 3PL logistics providers became the main driving force [3].

In general cold chain logistics can be represented as system of the organizing, management and controlling processes and operations with main objective to ensure goods safety within product lifecycle during their production, storage, transportation distribution and consumption stages. 
Taking into account current state of global logistics development and target markets dynamics, cold chains might have the highest growth potential. Based on 2017 assessment entire volume of the frozen products market is USD 255 bln, growing $4 \%$ annually during 2017-2021 period [6]. Volumes of overland reefer transportations have grown by 57\% during 1980-2018 period. Chilled warehouse space growth potential reaches $15 \%$ through 2023 [4].

Other than globalization and technical-technological preconditions of cold chain logistics development we can outline the following:

- ever increasing volumes of perishables trade;

- more demanding consumer requirements as far as finish goods quality and their manufacturing recourse are being concerned;

- cold chains regulation and procedures are becoming more strict;

- increasing competition on the main markets, that makes ransport ness of the production and distribution resources vital; possibility of continuous storage of goods with their further sales with minimum expense at the time of market peak season, gaining decent additional returns towards global seasonal fluctuations. Good example is that certain African countries have developed fresh goods and flowers production with clear focus on supplying those to EU countries;

- mutual responsibility of cold chain market players, that increases all processes transparency and recording;

- ecological challenges in achieving sustainability and food products loss minimization (only $1 / 3$ of all food manufactured globally reaches its end consumer. Global annual loss has been estimated on the level of USD $1 \mathrm{bln}$, with 200 Mio tons of product being wasted [6]);

- global social problems related to fighting with starvation and poverty, and so forth.

Qualitative and quantitative parameters of cold chains functioning and development are determined by the main features of goods - those result in material flows.

Qualitative and quantitative parameters of cold chains functioning and development are determined by the main features of goods - those result in material flows (table). These are mostly foodstuff, temperature sensitive pharmaceuticals, chemicals and medical devices. Other than set of typical threats affecting any cargo during transportation perishables are especially vulnerable and might be seriously damaged by unacceptable temperature changes. This is the main reasons that puts speed and reliability of cold chains functioning at first place.

Matching speed criterion by choosing appropriate transportation mode within the cold chain. Actual delivery time has to be the higher the longer delivery distance and the shorter product life cycle. This made airfreight a designated mode for long distance deliveries. Albeit as a downside of the mode would be fair to mention that goods might spent up to $80 \%$ of entire transportation time in regular environment conditions waiting for being onboarded. This increases risks of damage due to inadequate temperature mode [2]. 
Characteristic features of cold supply chains

\begin{tabular}{|c|l|}
\hline Features of goods in the cold chains & \multicolumn{1}{c|}{ Specific features of the cold chain } \\
\hline & $\begin{array}{l}\text { Increased requirements for speed and reliability; } \\
\text { the need for a high level of efficiency in organizing }\end{array}$ \\
& $\begin{array}{l}\text { logistics processes and participant integrity; } \\
\text { the high level of process control; }\end{array}$ \\
the need to use special technical resources and \\
technologies implementation; \\
fluctuations \\
the high cost of cold logistics; \\
cold chain operations outsourcing with 3PL operators
\end{tabular}

Source: developed by the authors.

In this context one of the main pillars is logistics infrastructure development: sufficiency of transportation ways and technical equipment of warehouses involved. For instance consistent enhancement of the road surface and intermodal connections along African coast made it possible to decrease foodstuff delivery time from 10 to 4 days for EU consumer markets [2].

One of the main conditions necessary to meet delivery time requirements is efficiency in organizing logistics processes that requires tight actions coordination from all participants involved in the cold chain. Having said that main objective is to eliminate possible delays and congestions for the perishable goods flows on all transportation stages - from cargo preparation, which often requires high extant of integration with the manufacturers who ensure supply reliability, meaning cargo is preliminary chilled to a required temperature level, packed and prepared for dispatch, and ending customs clearance of goods (followed by different type of exams: customs inspection, pharmaceutical, biological, sanitary and others controls) and first/ last mile operations (cargo in/out storage and consequent hand over of goods to the ultimate consumer).

Threat of perishable goods losing their consumption properties during transportation process requires special technical resources and technologies implementation. Existing resources are divided into 3 main categories: active refrigerators and freezers, reefer transport; passive - ranspo-containers, ranspo-bags, coolant elements, i.e. dry ice, gel packs, eutectic plates, liquid nitrogen; temperature control devices [1].

Storage premises have to be equipped with coolant equipment in combination with technical recourses that allow to ensure proper temperature, humidity and illumination levels involving wide variety of packaging option. Controlled ripening technologies (biotechnologies), transportation and storage can increase product life cycle and yields. For instance reefer containners can enhance chilled meat life cycle by 25 days, from 30-35 to 55-60 days, hence achieve marginal market potential for the product [2]. 
Reefer containers application makes even more sense for international trade operations. According to 2018 data reefer containers are accountable for Mio 2.9 TEU and $5 \%$ of global ISO-containers fleet [3]. Main recognizable feature of all reefer containers is that all of them are painted in white, this allows to reduce heating effect caused by the environment and solar activity. For seafreight transportation purposes dedicated low TEU capacity vessels and specialized port terminals are being utilized on the routes.

As far as continuation and responsiveness of cold chain processes are being concerned temperature control and recording technologies, ELD and GPS equipped loggers are becoming of most importance.

Due to the complexity of the organization of processes and their technical and technological support, as well as the stringent requirements for product quality by regulators and consumers the cold chain operations outsourcing with $3 P L$ operators is becoming more widely used. According to analytical overland market survey the following 5 LSPs (logistic service providers) have been mentioned - C.H. Robinson Worldwide, DB Schenker, Deutsche Post DHL Group, FedEx, Knight-Swift Transportation [7].

One of the key features of the cold chain is diversity of the products moved within the same flow. Classes of goods moved might have different cargo characteristics that require individual approach for their transportation and storage. There are 5 main temperature standards for cold chain moved goods [3]:

- Deeply frozen $(-25 \mathrm{C}$ through $-30 \mathrm{C})$ most commonly used in the delivery of seafood (especially shrimp) and ice cream;

- Frozen $(-10 \mathrm{C}$ through $-20 \mathrm{C})$ - frozen meat and pastry transportations;

- Chilled $(+2 \mathrm{C}$ through $+4 \mathrm{C})$ - fruits, vegetables, chilled fresh meat;

- Pharmaceuticals $(+2 \mathrm{C}$ through $+8 \mathrm{C})$ - majority of medications and vaccines;

- Banana $(+12 \mathrm{C}$ through $+14 \mathrm{C})$ - one of the most important commodities moved within cold chain, bananas are accountable for $20 \%$ of entire seafreight reefer containers transportations [2]. Also this temperature mode fits majority tropical fruits and vegies transportations.

Widely diverse range of cold chain moved merchandise predetermines variety of technical and technological support - transportation equipment, cargo handling and product storage are set to fit particular product requirements. To be precise majority of storage facilities are divided in several zones with different temperature-moisture settings. Each zone is dedicated to store specific group of goods, it is equipped with different type of storage refrigerators, i.e. freezers for deeply frozen meat and poultry storage; chilled warehouses for dairy, cheese and sausage; chilled warehouses for fruits, vegies, flowers; dedicated sections for bananas and other fruits ripening; chilled sections for meat and sausage chilling; special shock freezing sections for meat, fish, dumplings, berries, mushrooms and so forth. 
Also wide variety of products that is being ordered by large grocery chains determined large chilled Distribution Centers (DCs) (cold storage distribution facilities) development that act as an intermediary within cold chain. Chilled DCs hold vast majority of SKUs and supply to all main regional markets (for example Loblow Companies, Canada) [3]. This allows to achieve decent economy of scale effect.

Specific product features orientation within cold chain can be explainned with ever growing specialization and segmentation of temperaturecontrolled moves in several market segments. To be more specific we determined clear focus of certain 3PL providers either with frozen products deliveries or exceptionally chilled products or even deeper dedication to a specific commodity group.

Special features of goods outline that one of the common characterristics of cold chain merchandise flows is their high value. Higher ransporttation and storage cost are caused by a number of factors:

- special equipment that very often has to be electricity powered, besides its high production cost has relatively long ROI cycle. For instance production cost of a reefer container is $6 \mathrm{x}$ higher than standard dry container (USD 30k for reefer vs USD 5k for dry 40 foot container). At the same time reefer container has $12 \%$ less space and higher empty container equipment mass [3]. Freight rates for reefer transportations are higher with chilled cargo freight rates more affordable than frozen. Also all equipment being used within the cold chain has to be in good technical condition and operate properly, this requires regular equipment inspections and higher maintenance cost;

- additional electricity and fuel consumption caused by necessity to retain certain specific temperature mode and faster steaming for dedicated reefer vessels;

- more costly transportation modes using due to delivery time restrictions;

- extra labor caused by the numerous additional operations i.e. reefer equipment plug-in/plug-out; extended processes control, monitoring and recording; cargo preparation for transportation, preliminary chilling, processing and packaging, etc. Besides that labor cost itself with cold logistics is typically higher due to higher staff qualification requirements that ensures necessary compliance and effectiveness level;

- limited cargo consolidation abilities affected by cargo matching requirements and time sensitiveness that doesn't accept longer transportation unit loading time. Hence unit transportation cost is higher within the cold chain.

Based on every outlined cold chains features, we can make Ukrainian cold logistics market evaluate. First of all it has great growth potential relying on trade volumes developments and increase of the fresh products range that have been offered to an ultimate consumer. According to State statistics service of Ukraine during 2017-2020 period ones foresee higher relative density of temperature sensitive products within domestic and international trade portfolio product mixtures, namely fruits and vegies, raw and processed meat products, dairy, eggs, food grade oils and fats, confectionary,

ISSN 1727-9313. ВIСНИК КНТЕУ. 2020. № $2=53$ 
fish and seafood products. Perishable food products stake has gone up from $5.2 \%$ to $5.5 \%$ for wholesalers and from $20.1 \%$ to $24.5 \%$ for retailers, money wise bln 98,1 UAH and bln 139,7 UAH accordingly (figure 1).

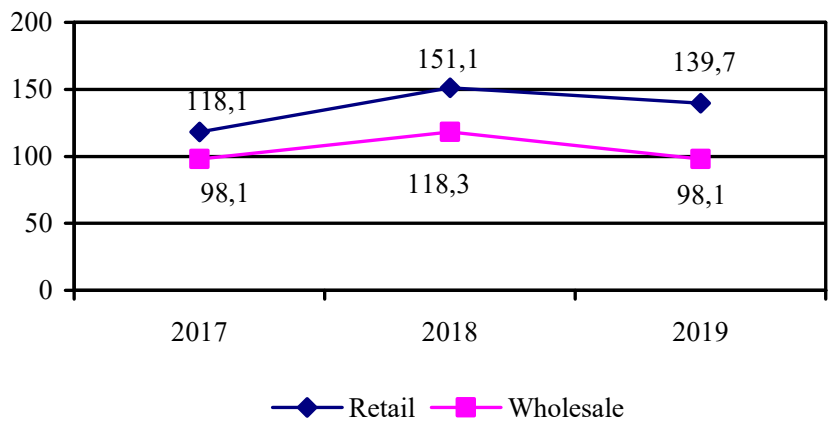

Figure 1. Dynamics of domestic trade in perishable food products in Ukraine in the period 2017-2019, bln UAH [8].

However perishable food products share in Ukrainian exports portfolio was $13.7 \%$ in 2019 that is almost $2 \%$ lower than in 2017 . At the same time perishables density in imports mixture increased by $0.5 \%$ and Mio 451.21 USD (figure 2). As a conclusion it is obvious that cold chain logistics is predominantly retail oriented that gives higher potential for LSPs development in this segment.

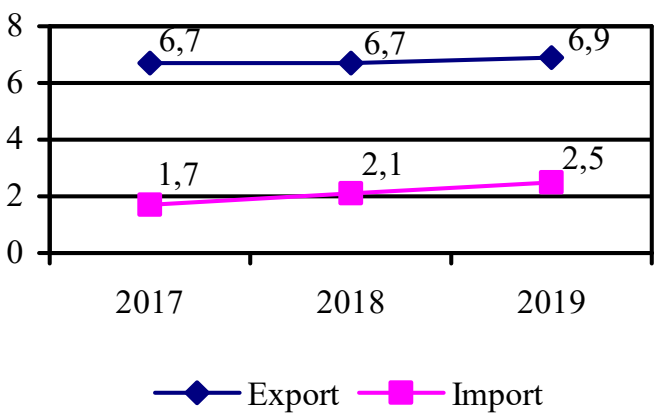

Figure 2. Dynamics of foreign trade in perishable food products in Ukraine in the period 2017-2019, bln USD [8].

We can outline that there is separate segment of LSPs that manages flows of highly sensitive to a temperature fluctuations products. One of the main market players is Ukrlogistica, that provides complex logistics services of storage and transportation of frozen and chilled products. Company operates as an asset own operator with temperature-controlled warehouses, 8 DCs and fleet of reefer trucks. Another good example within the segment is RLC company, that has multi-temperature class $\mathrm{A}$ and $\mathrm{B}+$ storage facilities under its management. 
Warehouse storage services for perishable products are also provided by Rhenus Logistics, company operates 9,000 sqm class A facility with $+4 \mathrm{C}$ through $+16 \mathrm{C}$; Raben Ukraine with climate control zones for fresh-logistics needs, $+2 \mathrm{C}$ through $+6 \mathrm{C}$; Business Group logistics and others. The number of logistics companies providing perishable goods transportation is more numerous: Kuehne+Nagel, Fiege Ukraine, FM Logistics Ukraine, Pan Logistics, AKRIS Logistics, Fresh logistics and other companies.

However 3PL operator involvement from the domestic services perspective remains rather an exception. According to Ekol Logistics general manager Mr. Andrii Golimbovskyi cold chain transportation services are typically being outsourced either by international companies or by systematic domestic companies, whereas market leaders from the segment prefer to build in house set up [9].

From the technical perspective domestic cold chains are being served with reefer trucks owned by retailers. International trade operations are accomplished with logistics companies' engagement involving different transportation modes with a higher level of technical recourses.

For instance export and import perishable goods deliveries are often done by seafreight transportation in reefer containers. In that sense main handling capacities are situated in Odessa port, PJSC "Odessa port refrigerator" with 13.5 thousand tons storage capacity for fruits'n' vegies and deeply frozen goods; container yards equipped with plug-in sources to accommodate 400 reefer container - HPC Ukraine and 330 reefer containers Brooklyn-Kiev Port [10].

Good indicator of reefer operation volumes growth at Odessa port is increased reefer capacities with CMA CGM BSMAR direct service, calling Brooklyn-Kiev Port terminal. Service connects the Black Sea, Mediterraneans and the Sea of Marmara [11]. Despite significantly smaller volumes we can indicated certain cold chain coverage with domestic river ways infrastructure, in 2018 the Dnipro river port was equipped with reefer container plug-in sources and started to handle reefer containers.

Entire cold chain market infrastructure in Ukraine is facing shortage temperature-controlled warehouse capacities, especially those constructed for multi-temperature operations and some shortage with cooling equipment at the existing facilities. As a result rental fees temperature-controlled storage have been increasing. As an example rental fees for class A perishable storage in Kiev region are on the level of UAH 200-250 per sqm that is $70 \%$ higher comparing to 2018 median value [13].

Domestic cold chain logistics operational expenses in Ukraine are several times higher comparing to developed countries. According to grocery chain Varus representative $1 \mathrm{~kg}$ of perishable goods encounters UAH 1.6 of logistics spend.

Conclusion. From the main cold chain risks perspective, we identified that Ukrainian cold chain logistics is underdeveloped technically and doesn't meet speed, responsiveness and cost effectiveness criterion requirements.

ISSN 1727-9313. ВІСНИК КНТЕУ. 2020. № $2=55$ 
Based on this, most relevant pillars of perishable product flows services development is domestic storage and handling infrastructure enhancement. This requires State program of investments involvement for new cold chain logistics objects construction; strategic optimization programs implemented by the main market players with clear objective of logistics cost reduction through energy saving technologies, economy of scale, processes automation and monitoring throughout entire perishable logistics chain.

\section{REFERENCES}

1. Krikavskyj E. V., \& Nakonechna, T. B. Vid holodnoi' logistiki do lancjugiv holodnih postavok. Lviv Politechnic National University Institutional Repositiry. Ena.lp.edu.ua. Retrieved from http://ena.lp.edu.ua [in English].

2. Dr. Rodrigue, J.-P. The logistics of global food systems. www.transportgeography.org. Retrieved from https://www.transportgeography.org/?page_id=12791 [in English].

3. Dr. Rodrigue, J.-P., \& Dr. Notteboom, T. The cold chain and its logistics. www.transportgeography.org. Retrieved from https://www.transportgeography.org/ ?page id=6585 [in English].

4. Vather, E. (2018). Best practices for managing cold chain logistics. P. 1. Retrieved from https://www.samsara.com/blog/best-practices-for-managingcold-chain-logistics- part-1 [in English].

5. Global refrigerated road transportation market 2017-2021: growth at $26.49 \%$ with carrier transicold, GAH refrigeration (2017). Culina\&Swift transportation dominating - research and markets. January, 27, Retrieved from https://www.businesswire.com/ news/home/20170121005373/en/Global-Refrigerated-Road-TransportationMarket-2017-2021-Growth [in English].

6. Refrigerated transportation and the cold chain: making innovation and globalization possible. www.winnesota.com. Retrieved from https://www.winnesota.com/ coldchain [in English].

7. Global refrigerated road transportation market 2018-2022. www.researchandmarkets.com. Retrieved from https://www.researchandmarkets.com/reports/47 [in English].

8. State Statistics Service of Ukraine. www.ukrstat.gov.ua. Retrieved from http://www.ukrstat.gov.ua [in English].

9. Logistika tovarov trebujuschih ocobih uslovi' hranenija. Trademaster.ua. Retrieved from https://trademaster.ua/articles/312494 [in English].

10. Perevalka gruzov. www.port.odessa.ua. Retrieved from http://www.port.odessa.ua.

11. Mezhdu Odessoj I portami Sredizemnogo morja nachali kursirovat' spezializirovannie kontejnerovozy, sposobnije perevozit' skoroportjaschijecja gruzy (2019). Retrieved from http://dumskaya.net [in English].

12. Porty Ukraine. Bsg.ukragroconsult.com. Retrieved from http://bsg.ukragroconsult.com [in English].

13. Analiz rynku holodil'nih skladiv v Kievi ta Kii'vskij oblasti: jakisni' holod zavzhdy v cini (2019). Retrieved from https://pro-consulting.ua/ua/pressroom/ analiz-rynka-holodilnyh-skladov-v-kieve-i-kievskoj-oblasti-kachestvennyj-holodvsegda-v-cene [in English].

The article submitted to editor's office on 18.03.2020. 
Харсун Л., Патковський С. Холодові ланцюги постачання продовольства: детермінанти управління і розвитку.

Постановка проблеми. Загострення конкурениії на світових ринках товарів і послуг, необхідність вирішення торговельних і соціальних проблем зумовлюють посилення вимог до функиіонування ланцњюгів постачання продукиії, особливо швидкопсувних продовольчих товарів, які характеризуються обмеженим терміном придатності і чутливістю до температурних режимів у процесі їх зберігання і транспортування. Врахування особливостей холодових ланцңюгів постачання (ХЛП) продовольства є передумовою ефективного застосування економічних, технічних та технологічних засобів управління ними.

Аналіз останніх досліджень і публікацій показав, щчо попри наявність окремих наукових доробок малодослідженими залишаються питання інтегрованого управління ХЛП, організації їх ефективного логістичного забезпечення.

Мета статті - проаналізувати, визначити і систематизувати характерні риси логістичного забезпечення ХЛП, оцінити сучасний стан логістичного обслуговування холодових ланцюгів постачання в Украӥні та визначити перспективні напрями його розвитку.

Матеріали та методи. У прочесі дослідження використано методи порівняльного аналізу, синтезу, систематизаиії, узагальнення.

Результати дослідження. Якісні й кількісні параметри функиіонування та закономірності розвитку ХЛП безпосередньо визначаються притаманними їм особливостями, які, в свою чергу, продиктовані характерними рисами самих товарів об'єктів їх матеріальних потоків: чутливістю до температурних коливань та неоднорідністю об'єктної складової. Особливостями ХЛП є підвищені вимоги до швидкості та надійності, потреба у високому рівні ефективності логістичних проиесів та інтегрованості учасників, високий рівень контролю процесів, необхідність використання спеціальних технічних засобів $і$ технологій, висока вартість холодової логістики, передання на аутсорсинг логістичних функиій 3PL операторам, спеціалізація та сегментація ринку холодової логістики, диференціація техніко-технологічного забезпечення, укрупнення й універсалізація холодових складів.

Виявлені ознаки ХЛП є орієнтиром аналізу ринку послуг холодової логістики України, який має потенціал для розвитку, зважаючи на позитивну динаміку обсягів торгівлі та розширення асортименту пропонованих кінцевим споживачам свіжих продовольчих товарів.

Висновки. Обслуговування ХЛП в Україні характеризується недосконалістю його техніко-технологічної складової, невідповідністю затребуваним параметрам швидкості, оперативності й економічності просування швидкопсувних товарів. 3 огляду на це, найбільш нагальними напрямами розвитку вітчизняної системи логістичного обслуговування матеріальних потоків, чутливих до температури продовольчих товарів, є: розбудова інфраструктури зберігання і перевалки швидкопсувних вантажів, щуо передбачає ініціювання державних програм із сприяння залученню інвестицій та фінансової підтримки будівництва об'єктів холодової логістики; впровадження учасниками ринку стратегічних програм з оптимізації ХЛП, спрямованих на зниження логістичних витрат, зокрема завдяки використанню енергоефективних технологій, економії на масштабі, автоматизаиї та моніторингу процесів по всьому ланцююгу постачання швидкопсувних товарів.

Ключові слова: холодова логістика, холодовий ланцюг постачання, швидкопсувні товари, температурний режим, логістичне забезпечення. 